\title{
TEACHERS' OPINIONS ON DIDACTIC TEXTS, AUXILIARY TEACHING MATERIALS AND „NON-DIDACTIC TEXTS” FOR THE TEACHING OF ICT OR DIGITAL TECHNOLOGIES
}

\author{
Vladislav HODIS
}

\begin{abstract}
The teaching process may be optimised through appropriate texts. The paper presents selected results of a questionnaire survey. It deals with opinions of teachers on the secondary level of basic school and lower level of multi-year gymnasium (grammar school) on selected types of didactic texts, auxiliary teaching materials and ,non-didactic texts" for teaching of Information and Communication Technologies (ICT) and digital technologies.
\end{abstract}

Key words: didactic text, auxiliary teaching material, ,, non-didactic text", teaching of ICT or digital technologies, teacher, questionnaire.

\section{NÁZORY UČITELŮ NA DIDAKTICKÉ TEXTY, POMOCNÉ MATERIÁLY PRO UČITELE A „NEDIDAKTICKÉ TEXTY“ PRO VÝUKU ICT ČI DIGITÁLNÍCH TECHNOLOGIÍ}

\begin{abstract}
Abstrakt: Výuku lze optimalizovat vhodnými texty. V článku jsou prezentovány vybrané výsledky dotazníkového šetreneni. Jedná se o názory učitelů 2. stupně základních škol a nižších ročníků víceletých gymnázií na vymezené druhy didaktických textů, pomocných materiálů pro učitele a „,nedidaktických textü " pro výuku informačních a komunikačních technologii (ICT) či digitálni technologií.
\end{abstract}

Klićová slova: didaktický text, pomocný materiál pro učitele, „nedidaktický text“, výuka ICT či digitálních technologií, učitel, dotazník.

\section{1 Úvod}

Ve školní výuce se používají pro učení žáka uzpůsobené texty (napřs. učebnice, pracovní sešit), které můžeme v souladu s J. Průchou (1998) označit jako didaktické texty.

Vedle didaktických textů jsou vytvářeny dále texty (metodické př́ručky apod.), které jsou určeny pro učitele. Tyto texty důsledně odlišujeme od didaktických textů a použiváme pro ně výraz pomocný materiál pro učitele. Označení používáme podle Pedagogického slovníku (2003), kde se tento výraz objevuje při vymezování pojmu metodická příručka.

Ve výuce se používají dále texty (články z časopisů, webové stránky apod.), které nejsou primárně vytvářeny pro učení žáka, a přesto mají význam ve vzdělávání. Pro tyto texty zavedeme označení ,nedidaktický text “ a budeme ho uvádět $\mathrm{v}$ uvozovkách, protože jsme se s tímto výrazem zatím nesetkali a vymezujeme jej v protikladu $\mathrm{k}$ didaktickému textu.

$\mathrm{Na}$ základě definice základního pojmu didaktický text, charakteru dané výuky i práce především J. Průchy (1998) a W. Walata (2004), jsme vymezili, př́p. stručně charakterizovali pro potřeby empirického výzkumu, jednotlivé druhy didaktických textů, pomocných materiálů pro učitele a „nedidaktických textư" pro obecně technické předměty zaměřené na informační a komunikační technologie (ICT) či digitální technologie. Témata $\mathrm{z}$ uvedené oblasti jsou také zastoupena $\mathrm{v}$ Rámcovém vzdělávacím programu pro základni vzděláváni (RVP $Z V)$, a to v samostatné vzdělávací oblasti Informační a komunikační technologie. Ve vzdělávací oblasti Člověk a svět práce je pak zahrnut volitelný tematický okruh Využití digitálnich technologií. Uváděná témata spolu souvisejí, proto $\mathrm{v}$ textu budeme používat označení informační a komunikačni technologie či digitální technologie, resp. ICT či digitální technologie a budeme tím označovat zaměření na vzdělávací oblast Informační a komunikační technologie a zároveň zaměření na tematický okruh Využití digitálních technologií ze vzdělávací oblasti Člověk a svět práce.

Vymezené druhy didaktických textů, pomocných materiáli̊ pro učitele, „,nedidaktických textů“ jsme předložili učitelům základních škol a víceletých gymnázií $\mathrm{k}$ hodnocení. Výsledky dotazníkového šetření uvádíme v následujícím textu, přičemž nejdříve budeme prezentovat cíl výzkumného šetření, dále stanovený problém a $\mathrm{k}$ němu formulované výzkumné předpoklady a hypotézy, popíšeme 
výzkumný vzorek, uvedeme výzkumné metody a nakonec prezentujeme dosažené výsledky.

\section{Cíl výzkumu, stanovený problém, výzkumné} předpoklady a hypotézy

Cílem výzkumného šetření bylo zjistit názory učitelů na didaktické texty a dále na pomocné materiály pro učitele a „nedidaktické texty“, které mohou významně doplňovat didaktické texty.

Byl stanoven následující problém:

P1: Jak hodnotí učitelé předložené druhy didaktických textů, pomocných materiálů pro učitele a „nedidaktických textů“ pro výuku ICT či digitálních technologií? Jsou rozdíly v odpovědích učitelů základních škol a učitelů víceletých gymnázií?

$\mathrm{K}$ problému $\mathrm{P} 1$ jsme formulovali tyto výzkumné předpoklady (VP) a hypotézy $(\mathrm{H})$ :

VP1.1: Učitelé nejvíce preferují z didaktických textů pro svou výuku CD-ROM s texty pro procvičení učiva, úlohami.

H1.1: Učitelé základních škol a učitelé víceletých gymnázií hodnotí význam předložených didaktických textů odlišně.

VP1.2: Učitelé nejvíce preferují z pomocných materiálů pro svou výuku WWW stránky pro učitele.

H1.2: Učitelé základních škol a učitelé víceletých gymnázií hodnotí význam předložených pomocných materiálů pro učitele rozdílně.

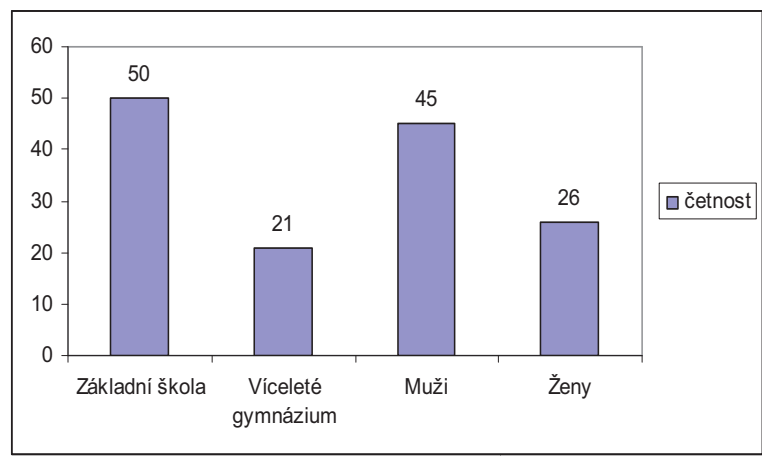

Obr. 1: Zast. učiteli̊ (n=71) podle druhu šk. a pohlaví.

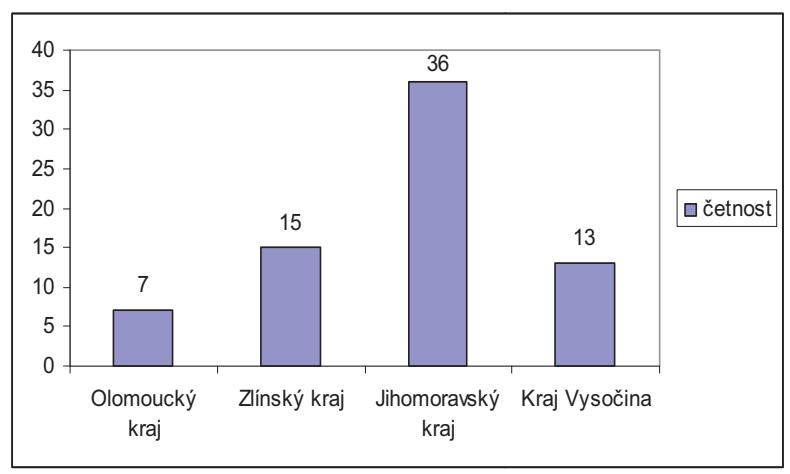

Obr. 2: Zastoupení učiteli̊ (n=71) podle kraje.
VP1.3: Učitelé nejvíce preferují $\mathrm{z}$,nedidaktických textů“ pro svou výuku WWW stránky.

H1.3: Učitelé základních škol a učitelé víceletých gymnázií hodnotí význam „,nedidaktických textư“ odlišně.

\section{Charakteristika výzkumného vzorku}

Výzkum byl zaměřen na učitele 2. stupně základních škol a nižších ročníků víceletých gymnázií. Získávání výzkumných dat probíhalo od února 2008 do dubna 2008.

Výzkumný vzorek tvoří celkem 71 učitelů, 7 učitelů je z Olomouckého kraje, 15 ze Zlínského kraje, 36 z Jihomoravského kraje a 13 z kraje Vysočina. Ve výzkumném vzorku je zastoupeno 50 učitelů základních škol a 21 učitelů víceletých gymnázií, 26 žen a 45 mužů. Věkový průměr respondentů je 37,84 let a průměrný počet roků praxe je 13,74.

Většina učitelů $\mathrm{z}$ výzkumného vzorku má vysokoškolské vzdělání pedagogického zaměření; ve vzorku jsou zastoupeni jak aprobovaní učitelé informatiky, popř. obecně technických předmětů, tak také neaprobovaní učitelé uvedených předmětů.

Základní charakteristika výzkumného vzorku je přehledně zobrazena $v$ diagramech na obr. 1 a 2.

\section{Výzkumné metody, rozdělení proměnných, homogenita rozptylů}

K získávání výzkumných dat byla použita metoda dotazování, konkrétně technika dotazníku. Pro zjištění názorů respondentů na dané texty či materiály pro uvedenou výuku byla v dotazníku použita numerická posuzovací škála.

Získaná data byla zapsána do tabulky v programu Microsoft Excel a dále vyhodnocována v programu Statistica 6.0.

Pro správné zvolení vhodné statistické metody k testování hypotéz H1.1, H1.2 a H1.3 jsme nejprve provedli ověření normálního rozdělení proměnných. K ověření byl použit chí-kvadrát test. Př́islušný výpočet byl realizován $\mathrm{v}$ programu Statistica 6.0, přičemž jsme nejdříve určili očekávané četnosti. V př́ípadě menší očekávané četnosti než je $5 \mathrm{v}$ dané kategorii, jsme provedli sloučení sousedních kategorií dohromady. $\mathrm{Na}$ základě daného ověření můžeme konstatovat, že proměnné z našeho vzorku splňují požadavek normálního rozdělení; $\mathrm{k}$ testování hypotéz je tedy použit Studentův t-test. Interpretaci výsledků získaných tímto testem předchází také splnění požadavku homogenity rozptylů v obou 
srovnávaných skupinách. Toto ověření jsme provedli F-testem. S výjimkou hodnocení př́slušných skupin učitelů na pomocný materiál pro učitele (CD-ROM obsahující texty k procvičování, úlohy, ukázky řešení) je ve všech ostatních prípadech splněna podmínka homogenity rozptylů. U proměnné, která nesplňuje uvedenou podmínku, byl použit v programu Statistica 6.0 Studentův t-test pro př́ípad nehomogenity rozptylů a pro kontrolu dále i neparametrický U-test Manna a Whitneyho. Hladina významnosti byla zvolena 0,05 .

\section{Výsledky}

V následujícím textu jsou uváděny výsledky ověřování výzkumných předpokladů a testování hypotéz $(\mathrm{H})$.
Průměrné hodnocení didaktických textů apod. je uváděno $\mathrm{v}$ tabulkách. Učitelé na numerické posuzovací škále (1 naprosto souhlasím, 2 souhlasím, 3 středně souhlasím, 4 spíš nesouhlasím a 5 naprosto nesouhlasím) měli označit souhlas nebo nesouhlas s potřebností předložených druhů didaktických textů apod. $\mathrm{k}$ výuce ICT či digitálních technologií.

\section{Didaktický text}

VP1.1: Učitelé nejvíce preferují z didaktických textů pro svou výuku CD-ROM s texty pro procvičení učiva, úlohami.

$\mathrm{Na}$ základě výsledků $\mathrm{v}$ tabulce 1 , můžeme konstatovat, že náš výzkumný předpoklad se potvrdil.

\begin{tabular}{|c|l|c|c|}
\hline Pořadí & \multicolumn{1}{|c|}{ Didaktický text } & $\begin{array}{c}\text { Aritmetický } \\
\text { průměr }\end{array}$ & $\begin{array}{c}\text { Směrodatná } \\
\text { odchylka }\end{array}$ \\
\hline \hline 1. & CD-ROM stexty pro procvičení učiva, úlohami & 1,87 & 1,00 \\
\hline 2. & $\begin{array}{l}\text { WWW stránky pro žáky (prezentace } \\
\text { aktualizovaných poznatků, úlohy, odkazy na } \\
\text { další stránky apod.) }\end{array}$ & 1,93 & 0,82 \\
\hline 3. & $\begin{array}{l}\text { Počítačový výukový program (zahrnující více } \\
\text { funkcí ve výuce - výklad, procvičování učiva } \\
\text { apod.) }\end{array}$ & 1,97 & 1,07 \\
\hline 4. & Pracovní sešit (v tištěné formě) & 2,93 & 1,22 \\
\hline 5. & Učebnice (klasická v tištěné formě) & 3,23 & 1,17 \\
\hline 6. & Slovník odborných termínů (v tištěné formě) & 3,32 & 1,13 \\
\hline
\end{tabular}

Tab. 1: Průměrné hodnocení didaktických texti̊ učiteli.

Pro doplnění výsledků uvádíme odděleně průměrné hodnocení učitelů základních škol a učitelů víceletých gymnázií.

\begin{tabular}{|c|l|c|c|}
\hline Pořadí & \multicolumn{1}{|c|}{ Didaktický text } & $\begin{array}{c}\text { Aritmetický } \\
\text { průměr }\end{array}$ & $\begin{array}{c}\text { Směrodatná } \\
\text { odchylka }\end{array}$ \\
\hline \hline 1. & CD-ROM s texty pro procvičení učiva, úlohami & 1,76 & 0,98 \\
\hline 2. & $\begin{array}{l}\text { Počítačový výukový program (zahrnující více } \\
\text { funkcí ve výuce - výklad, procvičování učiva } \\
\text { apod.) }\end{array}$ & 1,78 & 0,95 \\
\hline 3. & $\begin{array}{l}\text { WWW stránky pro žáky (prezentace } \\
\text { aktualizovaných poznatků, úlohy, odkazy na } \\
\text { další stránky apod.) }\end{array}$ & 2,02 & 0,87 \\
\hline 4. & Pracovní sešit (v tištěné formě) & 2,82 & 1,21 \\
\hline 5. & Učebnice (klasická v tištěné formě) & 3,04 & 1,14 \\
\hline 6. & Slovník odborných termínů (v tištěné formě) & 3,31 & 1,19 \\
\hline
\end{tabular}

Tab. 2: Průměrné hodnocení didaktických textio učiteli základních škol. 


\begin{tabular}{|c|l|c|c|}
\hline Pořadí & \multicolumn{1}{|c|}{ Didaktický text } & $\begin{array}{c}\text { Aritmetický } \\
\text { průměr }\end{array}$ & $\begin{array}{c}\text { Směrodatná } \\
\text { odchylka }\end{array}$ \\
\hline \hline 1. & $\begin{array}{l}\text { WWW stránky pro žáky (prezentace } \\
\text { aktualizovaných poznatků, úlohy, odkazy na } \\
\text { další stránky apod.) }\end{array}$ & 1,71 & 0,64 \\
\hline 2. & $\begin{array}{l}\text { CD-ROM s texty pro procvičení učiva, } \\
\text { úlohami }\end{array}$ & 2,14 & 1,01 \\
\hline 3. & $\begin{array}{l}\text { Počítačový výukový program (zahrnující více } \\
\text { funkcí ve výuce - výklad, procvičování učiva } \\
\text { apod.) }\end{array}$ & 2,43 & 1,21 \\
\hline 4. & Pracovní sešit (v tištěné formě) & 3,19 & 1,25 \\
\hline 5. & Slovník odborných termínů (v tištěné formě) & 3,33 & 1,02 \\
\hline 6. & Učebnice (klasická v tištěné formě) & 3,67 & 1,15 \\
\hline
\end{tabular}

Tab. 3: Prưměrné hodnocení didaktických textů učiteli víceletých gymnázií.

H1.1: Učitelé základních škol a učitelé víceletých gymnázií hodnotí význam předložených didaktických textů odlišně.

Pro testování platnosti hypotézy H1.1 byla stanovena nulová $\left(\mathrm{H}_{\mathrm{o}}\right)$ a alt. hypotéza $\left(\mathrm{H}_{\mathrm{a}}\right)$ :

$\mathrm{H}_{\mathrm{o}}$ : Učitelé základních škol a učitelé víceletých gymnázií hodnotí význam předložených didaktických textů stejně.

$\mathrm{H}_{\mathrm{a}}$ : Učitelé základních škol a učitelé víceletých gymnázií hodnotí význam předložených didaktických textů odlišně.
Vypočítaná hodnota signifikance při použití Studentova t-testu je uváděna $v$ tabulce 4 včetně závěru statisticky významného rozdílu, nemůžeme tedy odmítnout nulovou hypotézu.

Hypotéza H1.1 nebyla dokázána. Dílčí významné rozdíly se objevují jen u hodnocení učebnice a počítačového výukového programu, kdy učitelé základních škol hodnotí lépe učebnici i počítačový výukový program než učitelé víceletých gymnázií.

\begin{tabular}{||l|c|c||}
\hline \multicolumn{1}{|c|}{ Didaktický text } & $\begin{array}{c}\text { Vypočítaná hodnota } \\
\text { signifikance } \mathrm{p}\end{array}$ & $\begin{array}{c}\text { Významný rozdíl mezi } \\
\text { učiteli ZŠ a učiteli } \\
\text { víceletých gymnázií }\end{array}$ \\
\hline Učebnice (klasická v tištěné formě) & 0,0391 & ANO \\
\hline Pracovní sešit (v tištěné formě) & 0,2467 & $\mathrm{NE}$ \\
\hline Slovník odborných termínů (v tištěné formě) & 0,9445 & $\mathrm{NE}$ \\
\hline $\begin{array}{l}\text { CD-ROM s texty pro procvičení učiva, } \\
\text { úlohami }\end{array}$ & 0,1417 & $\mathrm{ANO}$ \\
\hline $\begin{array}{l}\text { Počítačový výukový program (zahrnující } \\
\text { více funkcí ve výuce - výklad, procvičování } \\
\text { učiva apod.) }\end{array}$ & 0,0185 & $\mathrm{NE}$ \\
\hline $\begin{array}{l}\text { WWW stránky pro žáky (prezentace } \\
\text { aktualizovaných poznatků, úlohy, odkazy na } \\
\text { další stránky apod.) }\end{array}$ & 0,1512 & $\mathrm{~N}$ \\
\hline
\end{tabular}

Tab. 4: Porovnání hodnocení didaktických textů mezi učiteli základních škol a učiteli víceletých gymnázií.

\section{Pomocný materiál pro učitele}

VP1.2: Učitelé nejvíce preferují z pomocných materiálů pro svou výuku WWW stránky pro učitele.
$\mathrm{Na}$ základě výsledků $\mathrm{v}$ tabulce 5 musíme konstatovat, že náš výzkumný předpoklad se nepotvrdil. 


\begin{tabular}{|c|l|c|c|}
\hline Pořadí & \multicolumn{1}{|c|}{ Pomocný materiál pro učitele } & $\begin{array}{c}\text { Aritmetický } \\
\text { průměr }\end{array}$ & $\begin{array}{c}\text { Směrodatná } \\
\text { odchylka }\end{array}$ \\
\hline \hline 1. & $\begin{array}{l}\text { CD-ROM obsahující texty k procvičování, } \\
\text { úlohy, ukázky řešení }\end{array}$ & 1,58 & 0,86 \\
\hline 2. & $\begin{array}{l}\text { Počítačový výukový program k výkladu učiva } \\
\text { (demonstrace, simulace jevŭ, zařízení apod.) }\end{array}$ & 1,69 & 0,87 \\
\hline 3. & $\begin{array}{l}\text { WWW stránky pro učitele (metodické } \\
\text { návody, texty k výuce...) }\end{array}$ & 1,76 & 0,89 \\
\hline 4. & $\begin{array}{l}\text { Interaktivní učebnice (soubor výukových dat } \\
\text { k vyučování pomocí interaktivní tabule, } \\
\text { umožňuje výklad, interaktivní cvičení) }\end{array}$ & 2,00 & 1,04 \\
\hline 5. & $\begin{array}{l}\text { Počítačový výukový program } \\
\text { pro testování s klasifikací }\end{array}$ & 2,14 & 1,14 \\
\hline 6. & $\begin{array}{l}\text { Soubory úloh s výsledky, postupy řšsení } \\
\text { (v tištěné formě) }\end{array}$ & 2,37 & 1,09 \\
\hline 7. & $\begin{array}{l}\text { Metodické př́ručky k didaktickým textům (v } \\
\text { tištěné formě) }\end{array}$ & 2,48 & 1,00 \\
\hline 8. & $\begin{array}{l}\text { Tematické plány s doporučením uspořádání } \\
\text { učiva pro jednotlivé ročníky (v tištěné formě) }\end{array}$ & 2,70 & 1,05 \\
\hline 9. & Testy a testové manuály (v tištěné formě) & 2,77 & 1,10 \\
\hline
\end{tabular}

Tab. 5: Průměrné hodnocení pomocných materiáli̊ učiteli.

Dále uvádíme průměrné hodnocení pomocných materiálů odděleně učitelů základních škol a učitelů víceletých gymnázií.

\begin{tabular}{|c|l|c|c|}
\hline Pořadí & \multicolumn{1}{|c|}{ Pomocný materiál pro učitele } & $\begin{array}{c}\text { Aritmetický } \\
\text { průměr }\end{array}$ & $\begin{array}{c}\text { Směrodatná } \\
\text { odchylka }\end{array}$ \\
\hline \hline 1. & $\begin{array}{l}\text { CD-ROM obsahující texty k procvičování, } \\
\text { úlohy, ukázky řešení }\end{array}$ & 1,46 & 0,68 \\
\hline 2. & $\begin{array}{l}\text { Počítačový výukový program k výkladu učiva } \\
\text { (demonstrace, simulace jevú, zařízení apod.) }\end{array}$ & 1,56 & 0,86 \\
\hline 3. & $\begin{array}{l}\text { WWW stránky pro učitele (metodické } \\
\text { návody, texty k výuce...) }\end{array}$ & 1,70 & 0,84 \\
\hline 4. & $\begin{array}{l}\text { Interaktivní učebnice (soubor výukových dat } \\
\text { k vyučování pomocí interaktivní tabule, } \\
\text { umožňuje výklad, interaktivní cvičení) }\end{array}$ & 1,78 & 0,89 \\
\hline 5. & $\begin{array}{l}\text { Počítačový výukový program } \\
\text { pro testování s klasifikací }\end{array}$ & 2,02 & 1,04 \\
\hline 6. & $\begin{array}{l}\text { Metodické př́ŕručky k didaktickým textům (v } \\
\text { tištěné formě) }\end{array}$ & 2,30 & 0,91 \\
\hline 7. & $\begin{array}{l}\text { Soubory úloh s výsledky, postupy rošení } \\
\text { (v tištěné formě) }\end{array}$ & 2,31 & 1,02 \\
\hline 8. & $\begin{array}{l}\text { Tematické plány s doporučením uspořádání } \\
\text { učiva pro jednotlivé ročníky (v tištěné formě) }\end{array}$ & 2,50 & 0,99 \\
\hline 9. & Testy a testové manuály (v tištěné formě) & 2,72 & 0,99 \\
\hline
\end{tabular}

Tab. 6: Průměrné hodnocení pomocných materiálů učiteli základních škol.

\begin{tabular}{|c|l|c|c|}
\hline Pořadí & \multicolumn{1}{|c|}{ Pomocný materiál pro učitele } & $\begin{array}{c}\text { Aritmetický } \\
\text { průměr }\end{array}$ & $\begin{array}{c}\text { Směrodatná } \\
\text { odchylka }\end{array}$ \\
\hline \hline 1. & $\begin{array}{l}\text { CD-ROM obsahující texty k procvičování, } \\
\text { úlohy, ukázky řešení }\end{array}$ & 1,86 & 1,15 \\
\hline 2. & WWW stránky pro učitele (metodické & 1,90 & 1,00 \\
\hline
\end{tabular}




\begin{tabular}{|c|c|c|c|}
\hline & návody, texty k výuce...) & & \\
\hline 3. & $\begin{array}{l}\text { Počítačový výukový program k výkladu učiva } \\
\text { (demonstrace, simulace jevů, zařízení apod.) }\end{array}$ & 2,00 & 0,84 \\
\hline 4. & $\begin{array}{l}\text { Počítačový výukový program } \\
\text { pro testování s klasifikací }\end{array}$ & 2,43 & 1,33 \\
\hline 5.-6. & $\begin{array}{l}\text { Soubory úloh s výsledky, postupy řešení } \\
\text { (v tištěné formě) }\end{array}$ & 2,52 & 1,25 \\
\hline $5 .-6$. & $\begin{array}{l}\text { Interaktivní učebnice (soubor výukových dat } \\
\mathrm{k} \text { vyučování pomocí interaktivní tabule, } \\
\text { umožňuje výklad, interaktivní cvičení) }\end{array}$ & 2,52 & 1,21 \\
\hline 7.-8. & $\begin{array}{l}\text { Metodické př́ručky k didaktickým textům (v } \\
\text { tištěné formě) }\end{array}$ & 2,90 & 1,09 \\
\hline 7.-8. & Testy a testové manuály (v tištěné formě) & 2,90 & 1,34 \\
\hline 9. & $\begin{array}{l}\text { Tematické plány s doporučením uspořádání } \\
\text { učiva pro jednotlivé ročníky (v tištěné formě) }\end{array}$ & 3,19 & 1,03 \\
\hline
\end{tabular}

Tab. 7: Průměrné hodnocení pomocných materiáli̊ učiteli víceletých gymnázií.

H1.2: Učitelé základních škol a učitelé víceletých gymnázií hodnotí význam předložených pomocných materiálů pro učitele rozdílně.

Pro testování platnosti hypotézy H1.2 byla stanovena nulová $\left(\mathrm{H}_{\mathrm{o}}\right)$ a alt. hypotéza $\left(\mathrm{H}_{\mathrm{a}}\right)$ : $\mathrm{H}_{\mathrm{o}}$ : Učitelé základních škol a učitelé víceletých gymnázií hodnotí význam předložených pomocných materiálů pro učitele stejně.

$\mathrm{H}_{\mathrm{a}}$ : Učitelé základních škol a učitelé víceletých gymnázií hodnotí význam předložených pomocných materiálů pro učitele rozdílně.
Vypočítaná hodnota signifikance při použití Studentova $t$-testu je uváděna $v$ tabulce 8 včetně závěru statisticky významného rozdílu, nemůžeme tedy odmítnout nulovou hypotézu.

Hypotéza H1.2 nebyla dokázána. Dílčí významné rozdíly se objevují jen v př́ípadě metodické př́ručky, tematického plánu a interaktivní učebnice, kdy je učitelé základních škol hodnotí lépe než učitelé víceletých gymnázií.

\begin{tabular}{|c|c|c|}
\hline Pomocný materiál pro učitele & 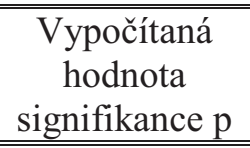 & $\begin{array}{l}\text { Významný rozdíl mezi } \\
\text { učiteli ZŠ a učiteli } \\
\text { víceletých gymnázií } \\
\end{array}$ \\
\hline $\begin{array}{l}\begin{array}{l}\text { Počítačový výukový program k výkladu učiva } \\
\text { (demonstrace, simulace jevů, zařízení apod.) }\end{array} \\
\end{array}$ & 0,0515 & NE \\
\hline $\begin{array}{l}\begin{array}{l}\text { Počítačový výukový program } \\
\text { pro testování s klasifikací }\end{array} \\
\end{array}$ & 0,1689 & NE \\
\hline $\begin{array}{l}\text { Metodické př́ručky k didaktickým textům (v } \\
\text { tištěné formě) }\end{array}$ & 0,0187 & ANO \\
\hline $\begin{array}{l}\text { Tematické plány s doporučením uspořádání } \\
\text { učiva pro jednotlivé ročníky (v tištěné formě) }\end{array}$ & 0,0102 & ANO \\
\hline $\begin{array}{l}\text { WWW stránky pro učitele (metodické návody, } \\
\text { texty k výuce...) }\end{array}$ & 0,3779 & NE \\
\hline $\begin{array}{l}\begin{array}{l}\text { Soubory úloh s výsledky, postupy řešení } \\
\text { (v tištěné formě) }\end{array} \\
\end{array}$ & 0,4489 & NE \\
\hline $\begin{array}{l}\text { CD-ROM obsahující texty k procvičování, } \\
\text { úlohy, ukázky řešení }\end{array}$ & 0,1520 & $\mathrm{NE}^{*}$ \\
\hline Testy a testové manuály (v tištěné formě) & 0,5215 & NE \\
\hline $\begin{array}{l}\text { Interaktivní učebnice (soubor výukových dat k } \\
\text { vyučování pomocí interaktivní tabule, umožňuje } \\
\text { výklad, interaktivní cvičení) }\end{array}$ & 0,0052 & ANO \\
\hline
\end{tabular}

Tab. 8: Porovnání hodnocení pomocných materiálů mezi učiteli základních škol a učiteli víceletých gymnázií. 
*V př́padě této proměnné nebyla splněna podmínka homogenity rozptylů. Proto jsme použili v programu Statistica 6.0 Studentův t-test pro prŕpad nehomogenity rozptylů. Pro kontrolu jsme dále aplikovali neparametrický U-test Manna a Whitneyho, který také neprokázal $(\mathrm{p}=0,2516>0,05)$ statisticky významný rozdíl v hodnocení.

\section{„Nedidaktický text"“}

VP1.3: Učitelé nejvíce preferují $\mathrm{z}$,nedidaktických textů“ pro svou výuku WWW stránky.

$\mathrm{Na}$ základě výsledků uvedených v tabulce 9 můžeme konstatovat, že náš výzkumný předpoklad se potvrdil.

\begin{tabular}{|c|l|c|c|}
\hline Pořadí & \multicolumn{1}{|c|}{ „Nedidaktický text“ } & $\begin{array}{c}\text { Aritmetický } \\
\text { prüměr }\end{array}$ & $\begin{array}{c}\text { Směrodatná } \\
\text { odchylka }\end{array}$ \\
\hline \hline 1. & WWW stránky & 1,77 & 0,76 \\
\hline 2. & Časopisy, noviny & 2,49 & 1,00 \\
\hline 3. & Encyklopedie & 2,52 & 0,98 \\
\hline 4. & $\begin{array}{l}\text { Uživatelské př́ručky (např. z nakladatelství } \\
\text { Grada, CP Books apod.) }\end{array}$ & 2,65 & 0,93 \\
\hline 5. & Odborné slovníky & 3,00 & 1,11 \\
\hline 6. & Návody k technice od výrobce & 3,23 & 1,20 \\
\hline 7. & Prospekty, reklamní letáky od firem & 3,70 & 0,96 \\
\hline
\end{tabular}

Tab. 9: Prüměrné hodnocení „,nedidaktických textü“ učiteli.

Dále v tabulkách 10 a 11 uvádíme průměrné hodnocení učitelů základních škol odděleně od průměrného hodnocení učitelů víceletých gymnázií.

\begin{tabular}{|c|l|c|c|}
\hline Pořadí & \multicolumn{1}{|c|}{ „Nedidaktický text“ } & $\begin{array}{c}\text { Aritmetický } \\
\text { průměr }\end{array}$ & $\begin{array}{c}\text { Směrodatná } \\
\text { odchylka }\end{array}$ \\
\hline \hline 1. & WWW stránky & 1,82 & 0,83 \\
\hline $2 .-3$. & Časopisy, noviny & 2,40 & 0,99 \\
\hline $2 .-3$. & Encyklopedie & 2,40 & 0,97 \\
\hline 4. & $\begin{array}{l}\text { Uživatelské př́ručky } \\
\text { (např. z nakladatelství Grada, CP Books } \\
\text { apod.) }\end{array}$ & 2,62 & 0,90 \\
\hline 5. & Odborné slovníky & 2,94 & 1,06 \\
\hline 6. & Návody k technice od výrobce & 3,22 & 1,07 \\
\hline 7. & Prospekty, reklamní letáky od firem & 3,64 & 0,90 \\
\hline
\end{tabular}

Tab. 10: Průměrné hodnocení ,"nedidaktických textü“ učiteli základních škol.

\begin{tabular}{|c|l|c|c|}
\hline Pořadí & \multicolumn{1}{|c|}{ „Nedidaktický text“ } & $\begin{array}{c}\text { Aritmetický } \\
\text { prúměr }\end{array}$ & $\begin{array}{c}\text { Směrodatná } \\
\text { odchylka }\end{array}$ \\
\hline \hline 1. & WWW stránky & 1,67 & 0,58 \\
\hline 2. & Časopisy, noviny & 2,70 & 1,03 \\
\hline 3. & $\begin{array}{l}\text { Uživatelské př́ručky } \\
\text { (nap̌r. z nakladatelství Grada, CP Books } \\
\text { apod.) }\end{array}$ & 2,71 & 1,01 \\
\hline 4. & Encyklopedie & 2,81 & 0,98 \\
\hline 5. & Odborné slovníky & 3,14 & 1,24 \\
\hline 6. & Návody k technice od výrobce & 3,24 & 1,48 \\
\hline 7. & Prospekty, reklamní letáky od firem & 3,86 & 1,11 \\
\hline
\end{tabular}

Tab. 11: Prưmèrné hodnoceni ,,nedidaktických textü “ učiteli víceletých gymnázií. 
H1.3: Učitelé základních škol a učitelé víceletých gymnázií hodnotí význam „nedidaktických textư“ odlišně.

Pro testování platnosti hypotézy $\mathrm{H} 1.3$ byla stanovena nulová $\left(\mathrm{H}_{\mathrm{o}}\right)$ a alternativní hypotéza $\left(\mathrm{H}_{\mathrm{a}}\right)$ :

$\mathrm{H}_{\mathrm{o}}$ : Učitelé základních škol a učitelé víceletých gymnázií hodnotí význam předložených „nedidaktických textư"s stejně.
$\mathrm{H}_{\mathrm{a}}$ : Učitelé základních škol a učitelé víceletých gymnázií hodnotí význam předložených „nedidaktických textư" odlišně.

Vypočítaná hodnota signifikance při použití Studentova t-testu je uváděna $v$ tabulce 12 včetně závěru statisticky významného rozdílu, nemůžeme tedy odmítnou nulovou hypotézu.

Hypotéza H1.3 nebyla dokázána.

\begin{tabular}{|l|c|c||}
\hline \multicolumn{1}{|c|}{ „Nedidaktické texty“ } & $\begin{array}{c}\text { Vypočítaná hodnota } \\
\text { signifikance } \mathrm{p}\end{array}$ & $\begin{array}{c}\text { Významný rozdíl mezi } \\
\text { učiteli ZŠ a učiteli } \\
\text { víceletých gymnází́ }\end{array}$ \\
\hline Návody k technice od výrobce & 0,9542 & $\mathrm{NE}$ \\
\hline Časopisy, noviny & 0,2615 & $\mathrm{NE}$ \\
\hline $\begin{array}{l}\text { Uživatelské př́ručky } \\
\text { (např. z nakladatelství Grada, CP Books } \\
\text { apod.) }\end{array}$ & 0,6988 & $\mathrm{NE}$ \\
\hline Odborné slovníky & 0,4855 & $\mathrm{NE}$ \\
\hline Prospekty, reklamní letáky od firem & 0,3893 & $\mathrm{NE}$ \\
\hline Encyklopedie & 0,1099 & $\mathrm{NE}$ \\
\hline WWW stránky & 0,4416 & $\mathrm{NE}$ \\
\hline
\end{tabular}

Tab. 12: Porovnání hodnocení ,nedidaktických textů“ mezi učiteli základních škol a učiteli víceletých gymnázií.

\section{Závěr}

Výzkumným šetřením, které odpovědělo na stanovený problém a $\mathrm{k}$ němu formulované výzkumné předpoklady a hypotézy, bylo zjištěno:

1. Učitelé $z$ předložených didaktických textů nejvíce preferují CD-ROM s texty pro procvičení učiva, úlohami. Učitelé základních škol a učitelé víceletých gymnázií se neliší v hodnocení předložených didaktických textů; dílčí statisticky významné rozdíly se objevují pouze při hodnocení učebnice a počítačového výukového programu.

2. Učitelé $\mathrm{z}$ předložených pomocných materiálů pro učitele nejvíce preferují $\mathrm{CD}$ ROM obsahující texty k procvičování, úlohy, ukázky řešení. Učitelé základních škol a učitelé víceletých gymnázií se neliší v hodnocení předložených pomocných materiálů pro učitele; dílčí statisticky významné rozdíly se objevují jen $\mathrm{v}$ př́ípadě hodnocení metodické příručky $\mathrm{k}$ didaktickým textům, tematického plánu s doporučením uspořádání učiva pro jednotlivé ročníky a interaktivní učebnice.

3. Učitelé $z$ př̀edložených „nedidaktických textư“ nejvíce preferují WWW stránky. Mezi hodnocením předložených „nedidaktických textů “ učiteli základních škol a učiteli víceletých gymnázií nejsou rozdíly.

Ze získaných výsledků vyplývá, že učitelé upřednostňují pro danou výuku elektronická média před tišstěnými texty. Elektronická média mohou být vhodnější než tištěné texty z několika důvodů. Vývoj ICT jde rychle kupředu a mění se např̀. programové vybavení, proto je třeba príslušné poznatky aktualizovat, což je $\mathrm{v}$ případě tištěných textů nejspíš obtížnější i dražší. $Z$ dalších důvodů lze uvést, že pojetí výuky ICT či digitálních technologií je činnostního charakteru a k její efektivitě je třeba mít pro práci na počítači př́slušné soubory. Tyto soubory je možno umístit pouze na elektronické médium (CD-ROM, WWW stránky apod.). Elektronická média umožňují také využívání multimédií, která mohou vhodně optimalizovat výuku.

$\mathrm{Na}$ základě získaných výsledků lze doporučit, aby při tvorbě didaktických textů pro výuku ICT či digitálních technologií byla preferována elektronická média (CD-ROM...) před tištěnými texty, popř. využívat možnosti jejich kombinovaní. Podobně je tomu také $\mathrm{v}$ př́ípadě pomocných materiálů pro učitele. 


\section{Literatura:}

1. CHRÁSKA, M. Úvod do výzkumu $v$ pedagogice. 2. vyd. Olomouc : Univerzita Palackého, 2006. 200 s. ISBN 80-244-1367-1.

2. LOUDA, Z. Řešené príklady v systému STATISTICA. 1. vyd. Praha : Česká zemědělská univerzita, Provozně ekonomická fakulta, 2004. 102 s. ISBN 80-213-1239-4.

3. MAREŠ, J. Učení z textu. In ČÁP, J.; MAREŚ, J. Psychologie pro učitele. 1. vyd. Praha: Portál, 2001, s. 473-492. ISBN 807178-463-X.

4. MAZÁK, E. Počítačové výukové programy a metodika jejich tvorby. Praha : Ústav školských informací, 1988. $119 \mathrm{~s}$.

5. Program pro interaktivní výuku [on-line]. [cit. 2008-01-22]. Nakladatelství FRAUS.

Dostupné z:

$<$ http://www.fraus.cz/ep/systemove ucebn ice/images/schema_ii_stupen.html>.
6. PRŮCHA, J. Učebnice: Teorie a analýzy edukačního média. Brno : Paido, 1998. 148 s. ISBN 80-85931-49-4.

7. PRŮCHA, J.; WALTEROVÁ, E.; MAREŠ, J. Pedagogický slovník. 4., aktualiz. vyd. Praha : Portál, 2003. 322 s. ISBN 80-7178-772-8.

8. Rámcový vzdělávací program pro základní vzdělávání (se změnami provedenými k 1. 9. 2007) [on-line]. [cit. 2008-03-21]. Výzkumný ústav pedagogický v Praze.

Dostupné z:

$<$ http://www.vuppraha.cz/soubory/RVPZV 2 007-07.pdf $>$.

9. WALAT, W. Modelowanie podręczników techniki-informatyki.

Rzeszów : Wydawnictwo Uniwersytetu Rzeszowskiego, 2004. 321 s. ISBN 83-7338-123-6.

\section{Kontakt:}

Mgr. Vladislav Hodis, Ph.D.

E-mail: VladislavHodis@seznam.cz 